\title{
INSTRUCCIONES A LOS AUTORES
}

Los manuscritos enviados a la Revista Médica de Chile deberán ajustarse al estilo y naturaleza de la Revista y a los «nniform Requirements for Manuscripts Submitted to Biomedical Journals» (Requisitos Uniformes para los Manuscritos Sometidos a Revistas Biomédicas) del International Committee of Medical Journal Editors, en su versión más reciente disponible en el sitio web www.icmje.org (hay una traducción al castellano disponible en www.wame.org).

Cualquiera sea la naturaleza del manuscrito (Artículo de investigación, casos clínicos, artículo de revisión o especial, carta al editor u otra) debe venir acompañado por la Guía de Exigencias para los Manuscritos y la Declaración de Responsabilidad de Autoría, con la identificación y firmas de todos los autores. Se pueden solicitar copias electrónicas del formato de estos documentos al correo revmedchile@smschile.cl.

Las instrucciones detalladas para la Revista Médica de Chile se deben consultar en la versión electrónica de la Revista publicada en www.scielo.cl o en www.smschile.cl. Los autores pueden solicitar una copia electrónica de estas Instrucciones al correo revmedchile@smschile.cl.

\section{INSTRUCTIONS FOR MANUSCRIPTS SUBMITTED IN ENGLISH}

Revista Médica de Chile accepts manuscripts submitted in English when: a) The work was done in an English-speaking country, by authors resident in that country, or b) The authors reside in a non-Spanishspeaking country and they feel themselves unable to prepare the manuscript in Spanish. In both circumstances, before submission the manuscript must have been revised/improved by individuals familiarized with scientific/medical writing in English. The manuscript should be prepared according to the format and style of Revista Médica de Chile, following the «niform Requirements for Manuscripts Submitted to Biomedical Journals»established by the International Committee of Medical Journal Editors, in its latest version published in the web site www.icmje.org.

More detailed instructions are available in the electronic version of Revista Médica de Chile, accessible at www.scielo.cl. In case of doubts, refer them to revmedchile@smschile.cl. 